\title{
Ohran ja rypsin viljelyn energiatase
}

\author{
Hannu Mikkola ${ }^{1)}$, Katri Pahkala ${ }^{2)}$, Teuvo Paappanen ${ }^{3)}$, Tuula Mäkinen ${ }^{4)}$ \\ ${ }^{1)}$ Maa- ja elintarviketalouden tutkimuskeskus, maatalousteknologian tutkimus, Vakolantie 55, 03400 \\ Vihti,hannu.j.mikkola@mtt.fi \\ 2) Maa- ja elintarviketalouden tutkimuskeskus, kasvintuotannon tutkimus, 31600 Jokioinen \\ katri.pahkala@mtt.fi \\ ${ }^{3)}$ VTT Prosessit, PL 1603, 40101 Jyväskylä, teuvo.paappanen@vtt.fi \\ 4)VTT Prosessit, PL 1601,02044 VTT, tuula.makinen@vtt.fi
}

Liikenteen biopolttoaineiden käytön edistämisen yhtenä tavoitteena on kasvihuonekaasupäästöjen vähentäminen. Biopolttoaineen jalostusaste ja tuotantoketju vaikuttavat siihen, miten paljon fossiilista energiaa tuotantoon joudutaan käyttämään. Jalostusasteen noustessa tuotantoon tarvittava energiapanostus saattaa olla merkittävä tuotettavan polttoaineen energiasisällöstä. Biopolttoaineiden tuotantoketjujen energiankulutuksen ja niistä aiheutuvien kasvihuonekaasupäästöjen tunnistaminen onkin oleellista, kun biopolttoaineilla suunnitellaan korvattavan fossiilisia polttoaineita.

Biopolttoaineiden raaka-ainetuotannon energiataseen selvittämiseksi tehtiin kaksi kuvitteellista tilamallia, joista toinen oli tärkkelysohraa viljelevä tila ja toinen rypsiä viljelevä tila. Ohran laskelmat tehtiin keskimääräisellä ja keskimääräistä tehokkaammalla tuotantointensiteetillä. Keskimääräisen intensiteetin sato oli $3500 \mathrm{~kg} / \mathrm{ha}$ ja tehokkaan $4200 \mathrm{~kg} / \mathrm{ha}$. Suuremman sadon saamiseksi oletettiin tarvittavan enemmän työtä, lannoitusta ja kasvinsuojelua kuin pienemmän sadon. Rypsin sato oli 1600 $\mathrm{kg} / \mathrm{ha}$. Suorakylvötuotantoketjujen satojen oletettiin olevan $10 \%$ tavanomaisen kyntöön perustuvan tuotantoketjun satoa pienempiä.

Tilojen koko, viljelyala ja koneistus päätettiin tutkimalla tilastotietoja (Maatilatilastolliset vuosikirjat 2001, 2002 ja 2004) sekä kysymällä ohran ja rypsin ostajilta, millainen on tyypillinen tärkkelysohraa ja rypsiä tuottava sopimustila. Peltotyövaiheiden polttoaineenkulutusluvut saatiin kirjallisuudesta. Laskelmaan otettiin mukaan myös lannoitteiden ja kalkin valmistukseen, niiden kuljettamiseen, siemenen tuotantoon ja sadon kuljettamiseen tarvittava energia. Laskelman ulkopuolelle on toistaiseksi jätetty torjunta-aineiden ja koneiden valmistukseen käytetty energiamäärä. Jos energian käyttö torjunta-aineiden valmistukseen olisi mukana, viljelyketjujen energian kulutus olisi 700 - 1500 MJ (6 $24 \%)$ suurempi. Koneiden valmistukseen käytetyn energiamäärän mukaan ottaminen lisäisi tuotantoketjujen energiankulutuksen noin puolitoistakertaiseksi.

Sekä ohran että rypsin viljelystä muodostettiin erilaisia tuotantoketjuja, joissa vaihtelivat perusmuokkauksen tapa ja intensiteetti, kylvötapa, varastointimenetelmä (lämminilmakuivaus tai ilmatiivis säilöntä), käytettävä lannoite (mineraalilannoite tai lietelanta) sekä kuivaukseen käytetty energianlähde (öljy tai hake).

Lannoitteiden ja erityisesti typen valmistukseen kuluu paljon energiaa. Lannoitteiden valmistuksen ja kuljetuksen osuus oli lähes puolet koko ketjun energian kulutuksesta. Paljon energiaa kuluu myös lämminilmakuivaukseen. Muokkaus ja puinti ovat peltotöistä eniten energiaa kuluttavat työvaiheet.

Perinteisissä ohran tuotantoketjuissa, joissa perusmuokkauksena oli kyntö tai sänkimuokkaus, uusiutumatonta energiaa kului 16 - $18 \%$ siemensadon energiasisällöstä. Säilöttäessä ohra ilmatiiviiseen siiloon energiaa kului $11-13 \%$ ja lannoitettaessa ohra lietelannalla ja käytettäessä haketta lämminilmakuivauksen energianlähteenä, 5 - $6 \%$ siemensadon energiasisällöstä. Tehokkaan tuotantointensiteetin ketjujen kulutus oli yhdestä kahteen prosenttiyksikköä pienempi kuin keskimääräisen. Perinteisissä rypsin tuotantoketjuissa uusiutumatonta energiaa kului $24-26 \%$ siemensadon energiasisällöstä. Käytettäessä lannoitukseen lietelantaa ja lämminilmakuivaukseen haketta uusiutumatonta energiaa kului $8 \%$.

Tämä tutkimus on osa VTT:n ja MTT:n yhteistutkimuksesta nimeltään "Liikenteen biopolttoaineiden ja peltoenergian käytön kasvihuonekaasutaseet ja uudet liiketoimintakonseptit - BIOGHG". Tutkimus päättyy huhtikuussa 2006 ja se kuuluu Tekesin ClimBus-teknologiaohjelmaan. Muut rahoittajat ovat: VTT, MTT, KTM, Neste Oil, PVO ja Vapo. 